\title{
Pelestarian Situs Kepurbakalaan Candi Muara Jambi di Kecamatan Muaro Sebo Kabupaten Muaro Jambi
}

\author{
Yusdi Anra', Amir Syarifuddin²
}

\begin{abstract}
The purpose of this research was to find out how far the society of Muaro Sebo district in Muaro Jambi Regency understands the preservation and conservation of Muaro Jambi temple complex. This research was qualitative research. The research was conducted in Muaro Sebo district, Muaro Jambi Regency, Jambi Province. The informants in this research were: 1) Indigenous Village Leaders of Muaro Sebo Village, 2) Management Group of Muaro Jambi Temple Complex, 3) Employees in the Department of Tourism Heritage, Jambi Province. 4) NonGovernmental Organizations, and 5) Muaro Sebo society of Muaro Jambi Regency. Data were collected by using interview, observation, and documentation studies. Data analysis techniques in this research were data reduction, data display / data presentation, conclusions and then verified. Based on the research findings and discussion, it can be concluded as follows. First, Performance of Cultural Heritage Conservation Management Group Muaro Jambi temple Complex has been arranged in the form of legal recognition by the Muaro Jambi District Government. Second, the utilization of Muaro Jambi temple complex as a superior tourism object that must be maintained and cared for by all people, especially, Muaro Sebo District society of Muaro Jambi Regency, with performance and local wisdom one form of values, attitudes, perceptions, behaviors and responses of the local community that interacts with a system of life with nature and the environment. Third, the obstacles in managing the utilization of this temple complex were very little awareness of the surrounding society to maintain and care to this temple sites. So, it takes hard work to continue and to increase awareness of the surrounding society to guard this temple site. Fourth, need active role of academics to assist in providing understanding, so that the Muaro Jambi enshrinement sites are getting better organized.
\end{abstract}

Keywords: preservation, archaeological sites

\section{PENDAHULUAN}

Provinsi Jambi memiliki keanekaragaman tipe hamparan alam goegrafi. Kekayaan ala mini sudah tentu merupakan potensi pergerakan dan pembangunan ekonomi daerah yang pada gilirannya merupakan modal utama pembangunan daerah terutama dari sector kepariwisataan.Undang-undang Dasar Negara 1945 pasal 32 menegaskan bahwa " pemerintah memajukan kebudayaan nasional Indonesia serta penjelasanya anatara lain menyatakan usaha kebudayaan harus menuju kearah kemajuan adab, budaya dan persatuan dengan tidak menolak bahan-bahan baru dari kebudayaan asing yang dapat memperkembangkan atau memperkaya kebudayaan banga sendiri. Ketetapan MPR Nomor II/MPR/1998 tentang GBHN menegaskan bahwa kebudayaan Indonesia yang mencerminkan nilai-nilai luhur bangsa harus dipelihara, dibina dan dikembangkan guna memperkuat kepribadian bangsa, mempertebal rasa harga diri dan kebangkitan nasional, memperkokoh jiwa persatuan dan kesatuan bangsa serta mampu menjadi penggerak bagi terwujudnya cita-cita bangsa di masa depan. Pelestarian situs kepurbakalaan candi muara Jambi di kecamatan Muara Sebo Kabupaten Muaro Jambi mempunyai arti penting bagi kebudayaan bangsa, khususnya untuk memupuk rasa kebangsaan Nasional serta memperkokoh kesadaran jati diri bangsa. Oleh karena itu pemerintah berkewajiban untuk berdasarkan pada peraturan perundang-undangan yang berlaku melindungi cagar budaya. Sejauh peninggalan sejarah merupakan benda cagar budaya. Maka demi pelstarian budaya bangsa benda cagar budaya harus dilindungi dan dilestarikan dan untuk keperluan ini maka benda cagar budaya perlu dikuasai oleh negara bagi pengamananya sebagai milik negara. Karenanya upaya melestarikan benda cagar budaya perlu dilaksanakan sebab selain untuk memupuk rasa kebangsaan nasional dan memperkokoh kesadaran jati diri sebagai bangsa yang berdasarkan Pancasila juga kepentingan Sejarah Ilmu Pengetahuan dan kebudayaan serta pemanfaatan lain dalam Rangka Kepentingan Nasional.

\footnotetext{
${ }^{1}$ Dosen Universitas Jambi
}

${ }^{2}$ Dosen Universitas Jambi 


\section{Landasan Teori \\ Tafsir Kebudayaan}

Memahami budaya atau kebudayaan, berarti memahami tindak laku manusia dalam kesehariannya berinteraksi dengan sesama dan lingkungannya. Memahami kerumitannya maka perlu terlebih dahulu kita menguraikannya secara defenisi. Kata budaya sendiri berasal dari bahasa sanskerta yakni buddhayah, yang merupakanbentuk jamak dari buddhi (budi atau akal) dan diartikan sebagai hal-hal yang berkaitan dengan budi,dan akal manusia.Hingga saat ini kata asli sansekerta 'budaya' tetap kita pakai, walau modrenisasi belakangan mengarahkan penggunaan kata 'kultur' yang sebenarnya diadopsi dari bahasa Inggris. Dalam bahasa Inggris, kebudayaan dikenal dengan sebutanculture, diambil dari bahasa latin 'colere', yaknimengolah. Kata colere dalam hal ini dapat diartikan juga sebagai mengolah tanah atau bertani. Pakar antropologi Ckifford Geertz (1996), dalam bukunya yang berjudul 'Tafsir Kebudayaan', lebih terperinci menguraikan apa yang dimaksud dengan kebudyaan, baik budaya bendawi maupun non-benda.kedua kebudyaan ini lahir dari proses yang digambarkan seperti pyramida terbalik, dimana ide atau gagasan menempati posisi puncak, disusul kemudian yakni keseharain masyarakat atau tinkah laku. Adapun poisi yetbawah yakni obyek dari kebudayaan itu sendiri, baik yang tadi sifatnya tangible maupun intangible (Geertz, 1996: 21).

\section{Tangible atau Budaya Bendawi}

Istilah tangible pertama kali dipopulerkan pada awal disahkannya Undang-Undnag No. 11 Tahun 2010 Tentang Cagar Budaya, dimana untuk lebih menekankan bahwa kajian cagar budaya bersifat benda diberi istlah tangible. Para arkeolog dan pelestari cagar budaya bendawi akhirnya secara tidak tertulis sepakat untuk menggunakan istilah ini dalam karya-karya tulis maupun kegiatan seminar yang disenggarakan. Pada dasarnya tangible merujuk pada hasil kebudayaan suatu masyarakat tertentu yang berwujud baik berupa benda, bangunan, struktur, situs maupun kawasan. Scovil (1977), dalam karya nya yang berjudul 'Concervation Archaeology' secara spesifik menjelaskan dan memberikan pemhaman konseptual terkiat warisan budaya bersifat tangible, bahwa "semua bukti-bukti fisik sisa kebudayaan yang ditingglkan oleh manusia dari masa lampau pada wilayah tertentu berguna untuk menggambarkan, menjelaskan dan untuk memahami bagaimana tingkah laku, cara berinteraksi, dan konsep yang mereka terapkan dalam membentuk relasi antara sesame dan lingkungan”.

\section{Intangible atau Budaya Non-bendawi}

Kata intangible atau cagar budaya non-bendawi maerupakan kebalikan dari tangible atau budaya bendawi. Intangible ini merujuk pada hasil kebudayan yang tidak memliki wujud material, namun dalam wujud abstrak berupa gerak, suara, makna, konsep, bahkan ide. Umumnya kajian intangible didalami oelah para antropolog, namun dalam kajian arkeologi juga digunakan untuk memperkuat data tangible guna mencari jawaban terkait fungsi dan makna objek bendawi. Demikian juga dalam kajian arsitketur rumah tradisional melayu Jambi ini, hasil budaya berupa intangible terdapat pada konsep pembagian tata ruang, makna arah hadap bangunan, maupun dapat menjawab terkait makna pada motif hias yang terdapat pada bangunan tradisional melayu Jambi. Dalam hal inilah nilai-nilai luhur kebudayaan melayu jambi diekspresikan dalam rumah tinggal, sekaligus menjadi pembelajaran dan petuah kepada masyarakat Jambi.

\section{Nilai Penting Cagar Budaya}

Kata nilai dalam Kamus Besar Bahasa Indonesia berarti sifat-sifat (hal-hal) yang penting atau berguna bagi kemanusian atau juga yang menyempurnakan mansuia sesuai hakikatnya. Melakukan penfasiran nilai terhadap hasil kebudayaan baik yang bersifat tangible maupun yang intangible, tentu tidak bisa dengan satuan harga material rupiah. Oleh karena itu dalam penafsiran nilai penting arsitketur rumah tradisional melayu Jambi, sehingga sangat penting untuk dilestarikan dan dikembangkan bukan dalam bentuk rupiah namun dalam bentuk lain. Beberapa pakar arkeologi maupun antropologi menentukan nilai penting dari hasil kebudayaan didasarkan atas ilmu pengetahuan dan kepentingan kemanusian. Sedangkan menurut sudut pandang Undang-Undang No. 11 Tahun 2010 Tentang cagar budaya, maka nilai penting dilihat dari segi kegunaannya bagi ilmu pengetahuan, sejarah, kebudayaan, sosial dan ekonomi. Pada penelitian arsitektur 
rumah tradisional melayu Jambi, patokan untuk nilai penting akan merujuk pada Undang-Undang No. 11 Tahun 2010 Tentang Cagar Budaya.

\section{METODE PENELITIAN}

Jenis penelitian ini adalah penelitian yang menggunakan pendekatan kualitatif. Lokasi penelitian dilakukan di Candi Muaro Jambi di Kecamatan Muara Sebo Kabupaten Muaro Jambi.Teknik pengambilan informannya adalah teknik snowball sampling. Teknik pengumpulan data dilakukan dengan cara observasi ke lapangan dan wawancara dengan informan melalui dokumentasi. Untuk memperkuat tingkat kesahihan hasil temuan data penelitian, maka peneliti menggunakan standar keabsahan data yang dikemukakan oleh Lincoln dan Guba (dalam Moleong, 2006: 326) yang terdiri dari 4 langkah yaitu: (1). Wawancara mendalam (interview) terhadap informan. (2) Ketekunan pengamatan untuk menemukan ciri-ciri dan unsur-unsur dalam situasi yang relevan, teliti dan berkesinambungan. (3) Triangulasi penggunaan teknik pengumpulan data berbeda-beda untuk pengecekan data yang terdiri dari trianggulasi teknik dan trianggulasi sumber. (4) Pengujian ketetapan referensi yaitu dengan pengarsipan data yang dikumpulkanmelalui studi naturalistic sebagai bahan untuk mengambil kesimpulan. Peneliti menjadikan dokumentasi dari arsip data yang diperoleh dari informan dari masyarakat, dan perangkat pemerintah daerah yang berkaitan dengan kondisi sosial ekonomi masyarakat.

Teknik Analisis Data dalam penelitian ini sesuai dengan pendapat Miles dan Huberman (1992: 20) yaitu: (1) Reduksi data, merupakan proses pemusatan perhatian dengan penyederhanaan, pengabstrakan, dan informasi data kasar yang terlihat dari catatan tertulis dilapangan. sehingga sesuai dengan rumusan masalah. Mereduksi data yaitu menerangkan data yang sudah terkumpul tentang kondisi percandian Muaro Jambi, lalu data diseleksi dan dikumpulkan ke dalam kategori situs percandian. Setelah itu jawaban yang sama dari informan dikelompokkan sehingga nampak perbedaan-perbedaan informasi yang didapatkan dari lapangan. Data yang masih belum lengkap dicari kembali dengan melakukan wawancara ulang dengan informan. Ketika penulis sudah diberi izin melakukan penelitian, peneliti melakukan observasi dan wawancara dan mendokumentasikannya. Wawancara pertama yang peneliti laksanakan adalah ketika memberi surat izin kantor BPCB dan Kelurahan maro Sebo. Sehingga peneliti

mendapatkan data tentang data tentang keadaan umum situs percandian Muara Jambi.

Setelah melakukan penelitian di kantor camat, peneliti melanjutkan menemui informan yang dianggap mengetahui dan mereka yang menguasai komplek percandian Muara Jambi dan dilanjutkan dengan informan lain sampai data yang dibutuhkan terjawab. (2) Display data, ini dilakukan dengan cara membuat berbagai tabel dari keseluruhan data yang diperoleh sehingga lebih msudah untuk menganalisis data yang diperoleh. Dalam penelitian ini, menyajikan data dilakukan dalam bentuk uraian singkat, tabel, identitas subjek dan pertanyaan penelitian. (3) Penarikan kesimpulan, ini diperoleh melalui data yang dikumpulkan dengan menggunakan kata-kata dan kalimat yang dimengerti, kemudian peneliti menarik kesimpulan yang akhirnya akan menjadi hasil penelitian.

\section{HASIL DAN PEMBAHASAN}

Kabupaten Muaro Jambi dengan ibukota Sengeti dan pusat pemerintahanya berada di Bukit Cinto Kenang terletak +_ $34 \mathrm{~km}$ dari Kota Jambi dan dapat ditempuh dengan kendaraan roda dua dan empat. Kabupaten Muaro Jambi hingga saat ini memiliki obyek wisata yang sangat terkenal dan dapat dikembangkan menjadi tujuan wisata yang menarik baik bagi wisatawan nusantara maupun mancanegara. Lokasi peninggalan sejarah kerajaan melayu ini terletak di Kecamatan Maro Sebo Desa Muaro Jambi. Secara keseluruhan peninggalan purbakala yang terdapat didalam situs Muara Jambi terdiri atas 80 buah menapo gundukan tanah yang mengandung struktur bata kuno dan diatasnya telah tumbuh tanaman semak ataupun pepohonan (duku dan lain sebagainya). Tinggalan lain yang tidak kalah menarik adalah adanya kolam besar yang terkenal dengan nama kolam telago rajo. Kolam ini merupakan tempat penampungan air di masa lalu. 6 bangunan candi dianataranya telah dipugar yaitu candi Gumpung, Candi Tinggi, Candi Kembar Batu, Candi Astano, Candi Gedong I, Candi Gedong II dan 4 buah bangunan candi yang belum dipugar yaitu candi Tinggi I dan Candi Kedaton, Candi Koto Mahligai dan Candi Sialang. Dari bentuk bangunan dan peninggalan benda-benda sejarah yang terdapat dikawasan candi Muara Jambi menunjukkan 
Budhis rentang VII sampai dengan ke XIII Masehi. Salah satu penemuan arca di candi Gumpung memperlihatkan adanya ciri-ciri yang banyak persamaanya dengan arca Pranamaparamitha Muara Jambi ini tidak berkepala lagi.

Dari sisi kesejarahan situs percandian muara Jambi tak pelak lagi merupakan media pembelajaran lahan penelitian para ahli arkeologi dan pakar sejarah local, nasional bahkan nasional. Kendati masih menjadi perdebatan setidak tidaknya situs percandian Muara Jambi telah mengisi Khasanah sejarah nusantara yang bukan dalam lingkup Indonesia.tetapi jauh sampai ke semenanjung Malaka dan selatan Thailand. Hubungan international dalam bidang pelayaran kebudayaan dan social kultural lainya tercermin oleh temuan-temuan lepas berupa keramik, uang, logam beberapa perangkat peperangan maupun alat-alat rumah tangga dan kelengkapan ritual keagamaan yang diindikasikan berasal dari Jazirah Arab, Benua Afrika, Eropa, India dan yang paling banyak dari belahan Cina. Rentang masanya pun menurut pakar arkeologi dan sejarah terbentang dari masa Abad VII sampai abad ke XIII bahkan ada temuan-temuan lepasnya menandai masa-masa abad ke XIX.

\section{SIMPULAN}

Kondisi fisik bangunan percandian belum seluruhnya tertangani karena memerlukan keahlian tersendiri dan membutuhkan pembiayaan yang besar serta waktu yang sedemikian lama. Untuk perbandingan pemugaran candi Borobudur di jawa tengah memerlukan waktu 12 tahunan. Biayanya pun di pasok dari bantuan lembaga keuangan international. Bahkan bakunya dari batu bata di candi muara jambi yang dianatara lebih tua dari Borobudur. Dari sisi minat khusus hal ini sebenarnya labih tua dari Borobudur.

Dari sisi kemasan bidang tertentu semisal kemah budaya keterampilan ekskavasi gebyar lukis dan sebagainya. Inipun perlu dipersiapkan tenaga professional arkeolog dan sejarah disamping kegiatan yang sudah berjalan saat ini. Kelembagaan pendukung masih sangat terbatas biro-biro perjalanan lebih banyak menangani ticketing ketimbang menjual paket wisata. Pranata social kemasyarakatan terkadang belum kondusif untuk melakoni suasana penerimaan kunjungan wisata bak itu berupa ada kebiasaan kebudayaan yang terakhir kondisi masyarakat yang mudah tergoncang oleh benturan emosional.

\section{DAFTAR PUSTAKA}

Henslin M, James. 2007. Sosiologi Dengan Pendekatan Membumi. Jakarta: Erlangga. (Haluan Padang, http://m.inilah.com/read/detail/1887841, 28 Juli 2012).

Idris Ridwan. 2011. “Perubahan Sosiaal Budaya dan Ekonomi Indonesia dan Pengaruhnya Terhadap Pendidikan.” Jurnal Lentera Pendidikan, vol 14. No. 2.

Irawan, M. Suparmoko. 1992. Ekonomika Pembangunan. Yogyakarta: BPFE

Lauer H. Robert. Perspektif Tentang Perubahan Sosial. Jakarta: Reneka Cipta

Miles, M.B. dan M.A. Huberman. 1992. Analisis Data Kualitatif: Buku Sumber Tentang Metode-metode Baru. Terjemahan Tjetjep Rohendi Rohidi, Jakarta: UI-Press.

Utomo, Bambang Budi dan Rima. 2012. “ Risiko Bencana Banjir Bandang”. Jurnal Teknik ITS, Vol. 1, No.1. 